\title{
MICROSTRUCTURAL EVOLUTION OF INCONEL 625 DURING HOT ROLLING
}

\author{
MIKROSTRUKTURNI RAZVOJ INCONELA 625 MED VROČIM \\ VALJANJEM
}

\author{
Franc Tehovnik, Jaka Burja, Bojan Podgornik, Matjaž Godec, Franci Vode \\ Institute of Metals and Technology, Lepi pot 11, 1000 Ljubljana, Slovenia \\ Prejem rokopisa - received: 2015-08-25; sprejem za objavo - accepted for publication: 2015-09-09
}

doi: $10.17222 /$ mit.2015.274

\begin{abstract}
This research provides an overview of the structural changes that occur during the hot rolling of the nickel superalloy Inconel 625. It is well known that microstructure control is of paramount importance concerning the mechanical properties of a material. The microstructure also plays an important role in processing materials at elevated temperature. In this work the hot-rolling behaviour of the Inconel 625 superalloy has been investigated. The specimens were hot rolled at a temperature of $1200{ }^{\circ} \mathrm{C}$ using different numbers of passes. During the hot rolling the loads were measured and recorded. A light microscope and an electron microscope, employing the electron-backscatter-diffraction (EBSD) technique, were employed to investigate the microstructure evolution, revealing a necklace dynamic-recrystallization mechanism.

Keywords: nickel superalloy, hot rolling, dynamic recrystallization, necklace mechanism
\end{abstract}

Raziskava obsega pregled strukturnih sprememb, ki se pojavijo med vročim valjanjem nikljeve superzlitine Inconel 625 . Znano je, da je kontrola mikrostrukture odločilnega pomena za mehanske lastnosti materiala. Mikrostruktura ima pomemben vpliv na predelavo materiala pri povišanih temperaturah. Preučevali smo superzlitino Inconel 625 med vročim valjanjem. Vzorci so bili vroče valjani pri temperaturi $1200{ }^{\circ} \mathrm{C}$ z različnimi števili prevlekov, med poizkusi smo merili tudi sile valjanja. Vzorce smo preiskali s svetlobnim in elektronskim mikroskopom s tehniko difrakcije povratno sipanih elektronov (EBSD). Raziskali smo razvoj mikrostrukture in potrdili dinamično rekristalizacijo preko "mehanizma ogrlice".

Ključne besede: nikljeva superzlitina, vroče valjanje, dinamična rekristalizacija, mehanizem ogrlice

\section{INTRODUCTION}

The Inconel nickel-chromium superalloy 625 is well known for its high strength and outstanding corrosion resistance. The strength of the Inconel alloy is derived from the stiffening effect of the molybdenum and niobium on its nickel-chromium matrix. This combination of elements is also responsible for its superior resistance to a wide range of corrosive environments of high severity as well as the high-temperature effects such as oxidation and carburization. Because of these properties, as well as fatigue and creep resistance, nickel-based superalloys are widely used in modern aero engines and gas turbines ${ }^{1,2}$.

During the hot deformation of metals and alloys, the material flow behaviour is often very complex. In order to optimize the final mechanical properties, control of the microstructure is of great importance ${ }^{3}$. Studies show that during hot deformation the work hardening, dynamic recovery (DRV) and dynamic recrystallization (DRX) often occur in the metals and alloys with a low stacking-fault energy ${ }^{4-6}$. Generally, DRX is not only an important softening mechanism, but also an effective method to refine the crystal grain size. Therefore, in the case of nickel-based alloys, which retain high strengths at high processing temperatures, causing high rolling loads, DRX plays a decisive role. The aim of the current work was to investigate the microstructure evolution and the nucleation mechanisms of the dynamic recrystallization of Inconel superalloy 625 during hot rolling.

\section{EXPERIMENTAL}

\subsection{Material}

Flat specimens of Inconel 625, with the chemical composition given in Table 1, were used for hot rolling tests. The specimens were cut from a thick hot-rolled plate; the specimens were $11 \mathrm{~mm}$ high, $145 \mathrm{~mm}$ long and $46 \mathrm{~mm}$ wide.

Table 1: Chemical composition of Inconel 625

Tabela 1: Kemijska sestava Inconela 625

\begin{tabular}{|c|c|c|c|c|c|c|c|c|c|}
\hline$w / \%$ & $\mathrm{C}$ & $\mathrm{N}$ & $\mathrm{Ni}$ & $\mathrm{Mo}$ & $\mathrm{Nb}$ & $\mathrm{Fe}$ & $\mathrm{Cr}$ & $\mathrm{Ti}$ & $\mathrm{Si}$ \\
\hline $\begin{array}{c}\text { Inconel } \\
625\end{array}$ & 0.012 & 0.018 & 63.4 & 8.7 & 3.5 & 0.15 & 21.8 & 0.29 & 0.24 \\
\hline
\end{tabular}

\subsection{Hot rolling}

Before the hot-rolling experiment the specimens were heated to a temperature of $1200{ }^{\circ} \mathrm{C}$ and soaked for 30 min in order to obtain a homogeneous temperature field of $1200{ }^{\circ} \mathrm{C}$ before each rolling experiment, regardless of the number of passes used. Up to five rolling passes were employed in this study. The logarithmic deformation per 
pass was 0.223 . The logarithmic deformation rate during the rolling was calculated to be $7.12 \mathrm{~s}^{-1}$ for the first, 7.96 $\mathrm{s}^{-1}$ for the second, $8.90 \mathrm{~s}^{-1}$ for the third, $9.95 \mathrm{~s}^{-1}$ for the fourth and $11.12 \mathrm{~s}^{-1}$ for the fifth pass. During the hot rolling the rolling loads were monitored using a measurement system with 2000 recordings per second, and converted to stress by dividing the loads by the contact area. The specimen temperature was measured at the beginning and after each rolling pass. After the hot rolling the rolled specimens were air cooled and prepared for microscopic examination.

\subsection{Microstructural analysis}

Light microscopy, SEM and SEM-based electronbackscatter-diffraction (EBSD) analyses were performed on the metallographic samples to reveal the microstructure and microstructure evolution during the hot rolling. The microstructure was examined optically using a Nikon Microphot FXA, while the EBSD data were collected in a FE-SEM JEOL JSM 6500F field-emission scanning electron microscope using an HKL Nordlys II EBSD camera and Channel 5 software. The EBSD mapping analyses were performed with samples tilted by $70^{\circ}$ using a $15 \mathrm{kV}$ accelerating voltage and a $1.5 \mathrm{nA}$ probe current. The EBSD map was generated in steps of $2 \mu \mathrm{m}$ using $619 \times 503$ grids with $4 \times 4$ binning and minimum 5 and maximum 6 band detection and an indexing rate between $92 \%$ and $97 \%$. The samples were prepared using a classic metallography preparation procedure, including grinding, polishing and etching, and colloidal silica polishing for the EBSD analysis.

\section{RESULTS AND DISCUSSION}

\subsection{Hot rolling of Inconel superalloy}

Although the degrees of deformation and the deformation rates used in this study were relatively high,

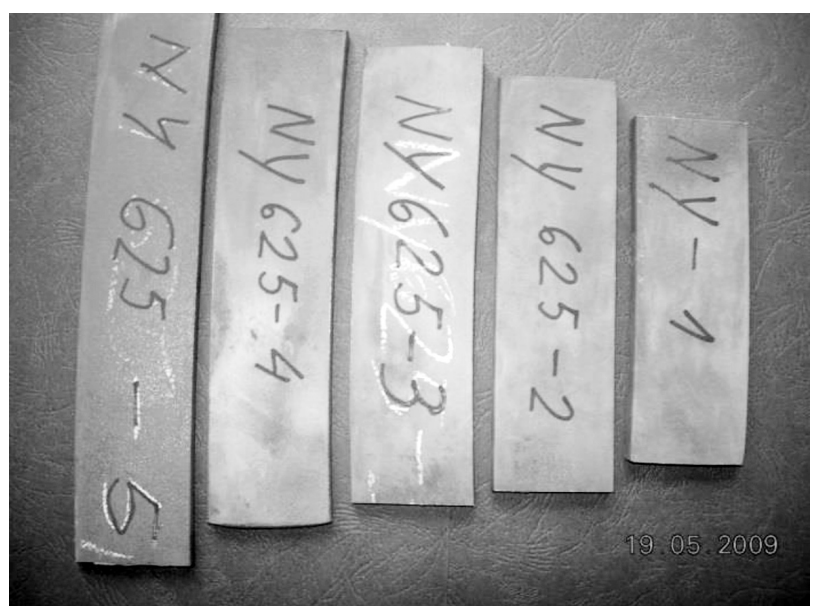

Figure 1: Hot rolled and air cooled specimens of Inconel 625, subjected to different numbers of rolling passes

Slika 1: Vroče valjani in na zraku ohlajeni vzorci Inconela $625 \mathrm{z} \mathrm{raz}$ ličnimi števili prevlekov no cracks or failures were observed at the edges of the hot-rolled specimens. The samples after hot rolling and air cooling are presented in Figure 1. However, the temperature drop after each rolling pass was found to be significant. The temperature at the end of first rolling pass was $1130{ }^{\circ} \mathrm{C}$, and the dropped to only $840{ }^{\circ} \mathrm{C}$ at the end of the fifth pass.

The corresponding loads recorded during the five rolling regimes (number of passes) are given in Figure 2. As shown, the loads increase with the increasing number of passes. The values recorded during the first pass were found to be similar for all five regimes, which also applies to all the other sequences. Furthermore, the temperatures measured during each pass did not vary by more than $15^{\circ} \mathrm{C}$ between consecutive tests and the five rolling regimes employed.

Nickel superalloys exhibit work hardening at high strains. When comparing the hot rolling of the nickel superalloy Inconel 625 to the superaustenitic steel 904L, done in previous work ${ }^{7}$, the nickel superalloy shows a greater deformation resistance. For this reason the initial degree of deformation during the industrial processing of nickel superalloy slabs has to be small. The deformation degrees can be higher when the onset of recrystallization begins at sufficiently high temperatures. However, special care must be taken when processing as-cast microstructures. Otherwise, the ductility of nickel alloys is very good and does not represent any concern. In the present case the microstructure of the initial specimens was already wrought, eliminating any concern about defects occurring due to insufficient ductility.

Figure 3 shows the stress evolution during each rolling pass for up to five passes. The corresponding logarithmic strain rates and temperatures measured at the end of each rolling pass are provided in the figure caption.

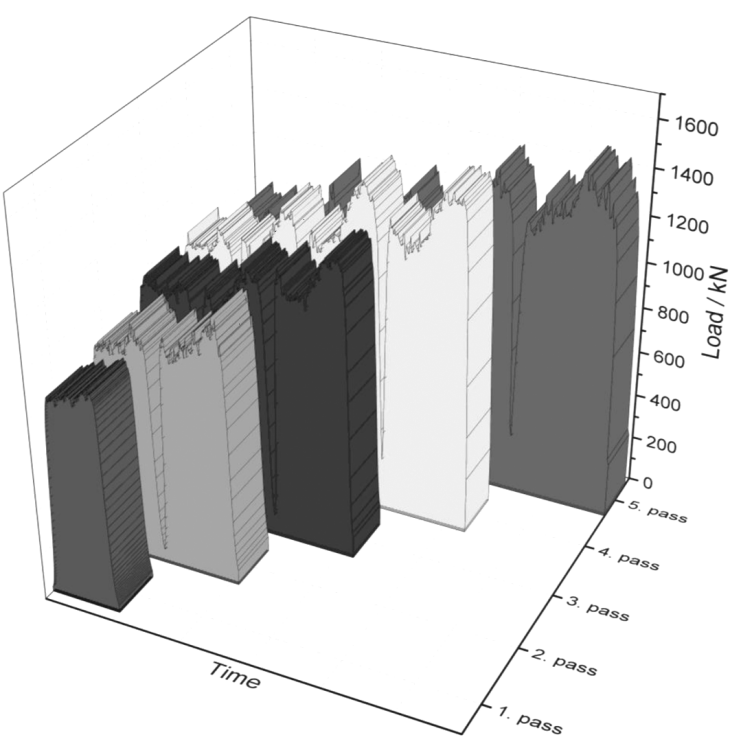

Figure 2: Rolling loads with different numbers of rolling passes Slika 2: Sile valjanja z različnimi števili prevlekov valjanja 


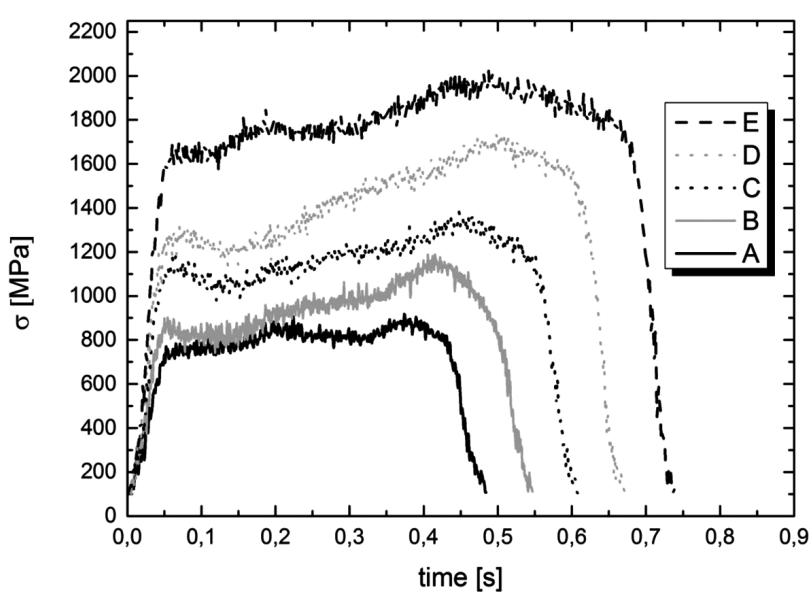

Figure 3: Calculated stress during rolling at different strain rates and the end of rolling temperatures, A first pass $\dot{\varphi}=7.12 \mathrm{~s}^{-1}, T=1131^{\circ} \mathrm{C}$, B second pass $\dot{\varphi}=7.96 \mathrm{~s}^{-1}, T=1040^{\circ} \mathrm{C}, \mathrm{C}$ third pass $\dot{\varphi}=8.90 \mathrm{~s}^{-1}, T=$ $983{ }^{\circ} \mathrm{C}, \mathrm{D}$ fourth pass $\dot{\varphi}=9.95 \mathrm{~s}^{-1}, T=940{ }^{\circ} \mathrm{C}, \mathrm{E}$ fifth pass $\dot{\varphi}=11.12$ $\mathrm{s}^{-1}, T=840{ }^{\circ} \mathrm{C}$

Slika 3: Izračunane napetosti med valjanjem pri različnih hitrostih deformacije in končnih temperaturah valjanja, A prvi prevlek $\dot{\varphi}=7,12$ $\mathrm{s}^{-1}, T=1131{ }^{\circ} \mathrm{C}$, B drugi prevlek $\dot{\varphi}=7,96 \mathrm{~s}^{-1}, T=1040^{\circ} \mathrm{C}, \mathrm{C}$ tretji prevlek $\dot{\varphi}=8,90 \mathrm{~s}^{-1}, T=983^{\circ} \mathrm{C}, \mathrm{D}$ četrti prevlek $\dot{\varphi}=9,95 \mathrm{~s}^{-1}, T=940$ ${ }^{\circ} \mathrm{C}$, E peti prevlek $\dot{\varphi}=11,12 \mathrm{~s}^{-1}, T=840{ }^{\circ} \mathrm{C}$

The stress during the first rolling pass reached values between $720 \mathrm{MPa}$ and $900 \mathrm{MPa}$, while the specimen temperature dropped from $1200{ }^{\circ} \mathrm{C}$ to $1130{ }^{\circ} \mathrm{C}$. During the second rolling pass the stress was between $790 \mathrm{MPa}$ and $1180 \mathrm{MPa}$ and the temperature was $1040{ }^{\circ} \mathrm{C}$. For the third rolling pass the stress increased to 990 and 1360 $\mathrm{MPa}$ and final temperature dropped to $980{ }^{\circ} \mathrm{C}$. During the fourth and fifth rolling passes the stress was between

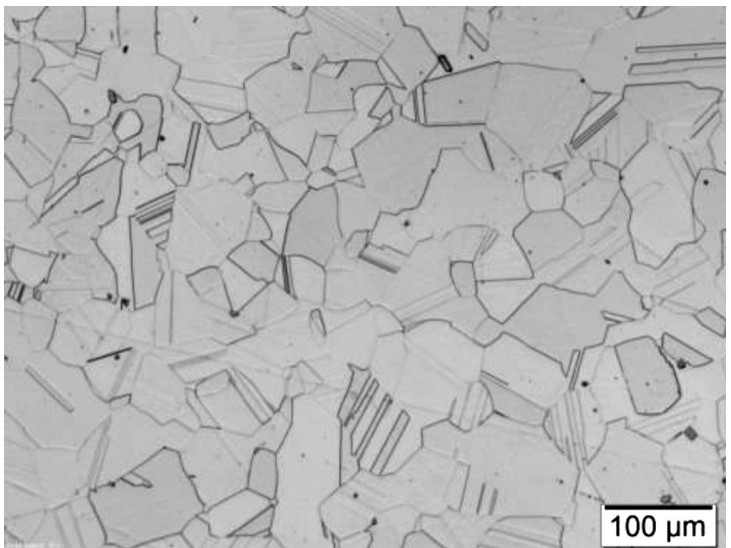

Figure 4: Light micrograph of the studied superalloy microstructure before hot deformation

Slika 4: Svetlobni posnetek mikrostrukture preiskovane superzlitine pred vročo deformacijo

$1180 \mathrm{MPa}$ and $1710 \mathrm{MPa}$, and between $1610 \mathrm{MPa}$ and $2000 \mathrm{MPa}$, respectively. On the other hand, the specimen temperature decreased to $940{ }^{\circ} \mathrm{C}$ after the fourth, and even down to $840{ }^{\circ} \mathrm{C}$ after the last, rolling pass. Due to the elongation of the specimen the rolling time also increased from $0.48 \mathrm{~s}$ for the first pass to $0.74 \mathrm{~s}$ for the fifth pass.

The material's resistance to deformation increases for each rolling pass. This is the product of the decreased temperature, increased strain rate and the accumulation of strain. However, DRX did take place and partially softened the material, as was revealed by the microstructure analysis given in Section 3.2. The dispersion of the load data during rolling shown in Figure 2 is attributed
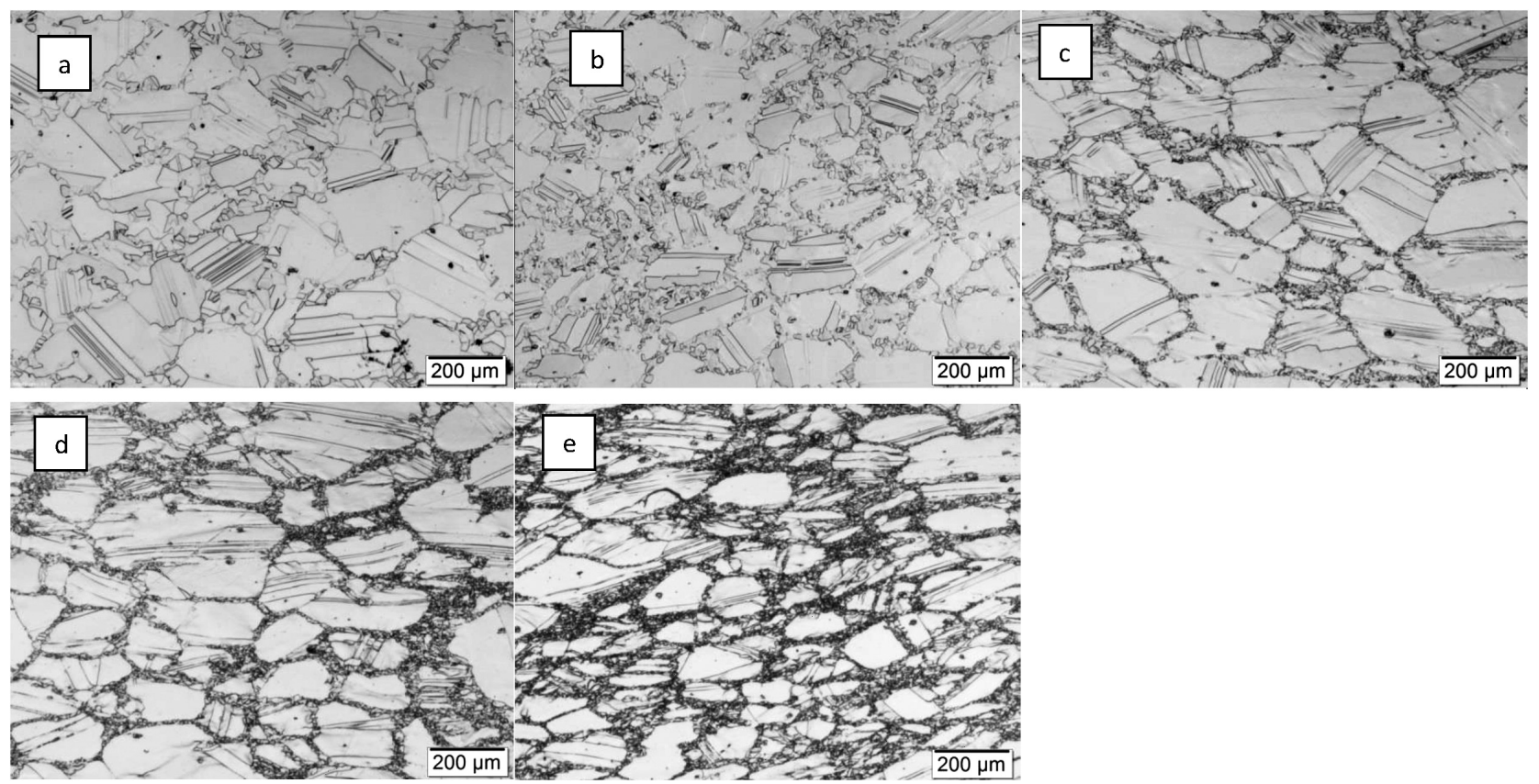

Figure 5: Microstructure of specimens after the hot rolling: a) after the first pass, b) after the second pass, c) after the third pass, d) after the fourth pass, e) after the fifth pass

Slika 5: Mikrostruktura vroče valjanih vzorcev: a) po prvem prevleku, b) po drugem prevleku, c) po tretjem prevleku, d) po četrtem prevleku in e) po petem prevleku 
to the measurement error and DRX, while the gradual increase of the stress during a single pass is attributed to the sample cooling.

\subsection{Microstructure}

Figure 4 shows the initial microstructure of the Inconel 625 before hot deformation. The specimen was annealed at $1200{ }^{\circ} \mathrm{C}$ for $30 \mathrm{~min}$, followed by water quenching, used to obtain a fine, homogeneous $\gamma$ phase with carbides solute in the matrix. It is clear that the microstructure consists of equiaxed grains with a mean grain size of $80 \mu \mathrm{m}$ and a large number of annealing twins in the austenite grains, typical for alloys with a low stacking-fault energy ${ }^{6}$.

The microstructure of the hot-rolled and air-cooled specimens obtained for a different number of rolling passes is given in Figure 5.

The start of the recrystallization process is visible from Figure 5a, showing the microstructure of the Inconel 625 alloy subjected to a single rolling pass. The DRX occurs through the so-called necklace mechanism, forming at the grain boundaries. After starting at some individual boundaries, as seen in Figure 5a, the recrystallized grains start to appear along most of the grain boundaries as the number of rolling passes and the deformation rate increase (Figure 5b). The recrystallization proceeds by increasing in number and decreasing in size of the new grains (Figure 5c), forming along all the boundaries (Figure 5d) and finally representing a significant part of the microstructure and regularly appearing at the deformation twin boundaries (Figure 5e).

Figure 5 shows that newly formed twins exist in the original deformed grains. It has been reported that the formation of twinning plays an important role for the nucleation process during DRX in materials with a low stacking-fault energy ${ }^{6}$. Higher grain-boundary mobility results in the nucleation of the twins, which act as the main activate nucleation mechanism of DRX for nickelbased superalloys deformed at higher temperatures. This accelerates the bulging and the separation of bulged parts from the original grains ${ }^{8}$. The amount of twin boundaries increases with increased strain. Figure 5e clearly shows a large amount of recrystallized grains on the twin grain boundaries.

During the hot deformation of low-stacking-faultenergy metals, the plastic deformation leads to a serration of the grain boundaries. For the sufficient deformation level, the serrations can lead to the creation of new grains by bulging from the pre-existing grain boundaries ${ }^{9}$. Miura et al. ${ }^{10}$ showed that the nucleation of new grains occurs preferentially at the triple junctions. The triple junctions acting as nucleation sites can either be constituted solely of three or more high-angle grain boundaries, or also include some twins among the intersecting boundaries. The initial stages of DRX appear on the grain boundaries. The new recrystallized grains nucleate on the deformed grain boundaries and form a necklace around it $^{7,11-13}$, as visible in Figure 5c.

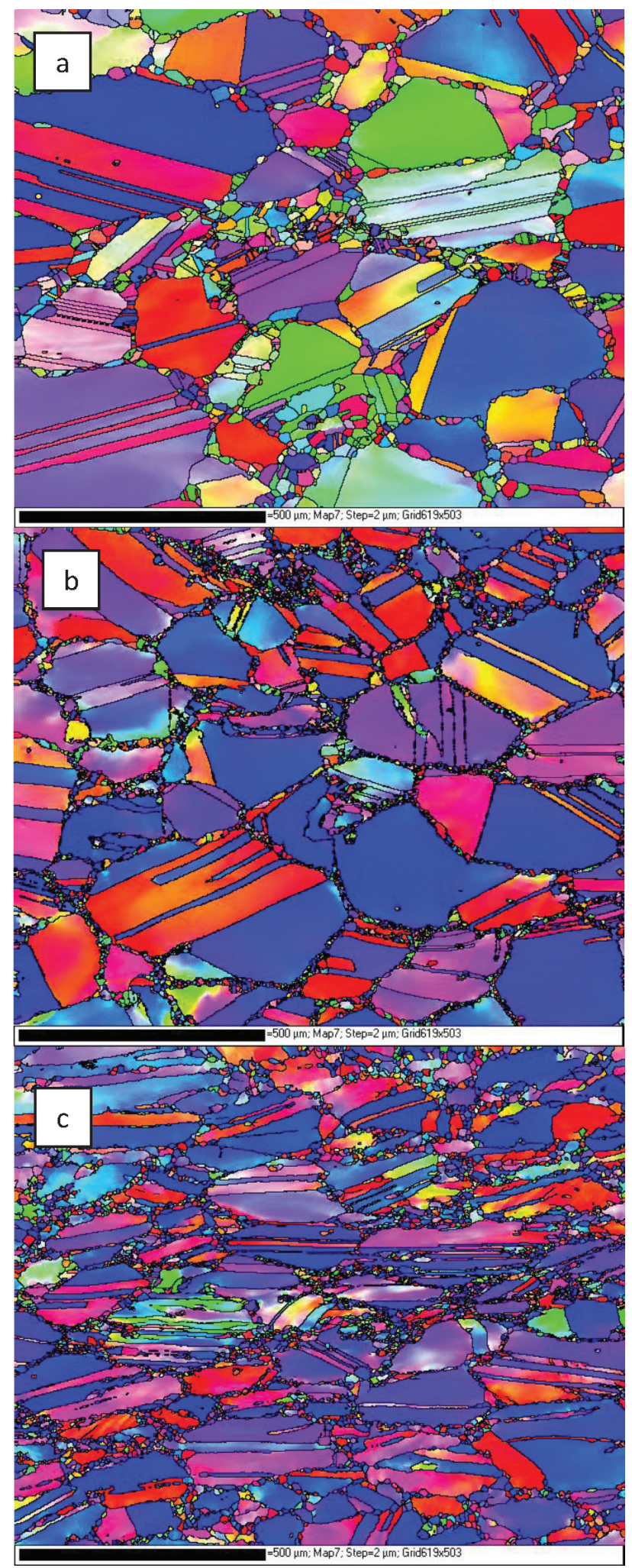

Figure 6: EBSD grain maps of samples: a) after one pass, b) after three passes and c) after five passes

Slika 6: EBSD ploskovna porazdelitev zrn: a) po prvem prevleku, b) po tretjem prevleku, c) po petem prevleku 
It has been reported that during deformation the cooling is slower due to the conversion of deformation energy to heat by adiabatic heating ${ }^{14}$. It is well known that the temperature rise during hot deformation can not only induce the process of DRX, but also lead to a rapid reduction in the work-hardening rate ${ }^{15}$. A higher strain rate will result in increased dislocation density, which in turn will dramatically reduce the recrystallization temperature ${ }^{16,17}$.

The deformation of the grains and the occurrence of new recrystallized grains were confirmed by the EBSD mapping shown in Figure 6. The microstructures presented correspond to the Inconel 625 superalloy at the end of hot deformation after: a) one pass, b) three passes and c) five rolling passes.

The analysis of the EBSD mapping images reveals large, non-recrystallized grains with twin grain boundaries and small recrystallized grains in the Inconel 625 alloy microstructure subjected to one rolling pass (Figure 6a). The evolution of the DRX structures clearly indicates that DRX starts predominantly at the boundaries of the deformed grains and not inside the grains ${ }^{18}$. Normal, large-angle grain boundaries are more susceptible to recrystallization than twin boundaries. In the case of a sample analysed after three rolling passes (Figure 6b) the non-recrystallized grains are slightly deformed, reflected in misorientation inside the grains and small recrystallized grains that are smaller compared to the sample after one rolling pass. This is due to the higher final deformation and the lower final temperature. The recrystallized grains do not remain isolated, but soon form closed networks, resulting in the well-known necklace structure ${ }^{19}$. For the most deformed sample obtained after five rolling passes (Figure 6c), large nonrecrystallized grains are severely deformed, which is reflected in the misorientation inside the grains. Furthermore, small recrystallized grains are smaller than in the case of three rolling passes, caused by an even higher final deformation rate and a very low final temperature. The analysis of the EBSD data of the different passes clearly shows that the recrystallized fraction increases with strain.

\section{CONCLUSIONS}

This research provides an overview of the structural changes occurring during hot rolling of the superalloy Inconel 625. Specimens were hot rolled from a temperature of $1200{ }^{\circ} \mathrm{C}$ with different deformation rates, obtained by changing the number of rolling passes. A light microscope and an electron microscope, employing the electron-backscatter-diffraction technique, were employed to investigate the microstructure evolution and the nucleation mechanisms of dynamic recrystallization.

The necklace DRX mechanism was found to be the dominant material-softening mechanism. The recrystallization begins at the deformed grain boundaries, being consistent with the necklace mechanism. However, at high deformation rates, new recrystallized grains also appear at twin boundaries.

The misorientation in the deformed grains increases with the lower rolling temperature of the deformation and the increased strain rate. The fraction of recrystallized grains increases with a higher degree of deformation, while the size of the recrystallized grains is reduced with the higher deformation rate and the lower temperature.

\section{REFERENCES}

${ }^{1}$ L. B. Getsov, A. S. Semenov, E. A. Tikhomirova, A. I. Rybnikov, Thermocyclic- and Static-Failure Criteria for Single-Crystal Superalloys of Gas-Turbine Blades, Mater. Tehnol., 48 (2014) 1, 255-260

${ }^{2}$ M. Mohan, R. Subramanian, Z. Alam, P. C. Angelo, Evaluation of the Mechanical Properties OF A Hot Isostatically Pressed Yttria-Dispersed Nickel-Based Superalloy, Mater. Tehnol., 48 (2014) 6, 899-904

${ }^{3}$ Y. C. Lin, X. M. Chen, A critical review of experimental results and constitutive descriptions for metals and alloys in hot working, Mater. Des., 32 (2011), 1733-1759, doi:10.1016/j.matdes.2010.11.048

${ }^{4}$ Y. C. Lin, M. S. Chen, J. Zhong, Constitutive modeling for elevated temperature flow behavior of $42 \mathrm{CrMo}$ steel, Comput. Mater. Sci., 42 (2008), 470-477, doi:10.1016/j.commatsci.2007.08.011

${ }^{5}$ F. Chen, Z. Cui, D. Sui, B. Fu, Recrystallization of $30 \mathrm{Cr} 2 \mathrm{Ni} 4 \mathrm{MoV}$ ultra-super-critical rotor steel during hot deformation, Part III: Metadynamic recrystallization, Mater. Sci. Eng. A, 540 (2012), 46-54, doi:10.1016/j.msea.2012.01.061

${ }^{6}$ A. Hoseini Asli, A. Zarei-Hanzaki, Dynamic Recrystallization Behavior of a Fe-Cr-Ni Super-Austenitic Stainless Steel, J. Mater. Sci. Technol., 25 (2009), 603-606

${ }^{7}$ F. Tehovnik, B. Žužek, B. Arh, J. Burja, B. Podgornik, Hot Rolling of the Superaustenitic Stainless Steel AISI 904L, Mater. Tehnol., 48 (2014) 1, 137-140

${ }^{8}$ Y. Wang, W. Z. Shao, L. Zhen, X. M. Zhang, Microstructure evolution during dynamic recrystallization of hot deformed superalloy 718, Mater. Sci. Eng. A, 486 (2008) 1, 321-332, doi:10.1016/j.msea. 2007.09.008

${ }^{9}$ T. Sakai, Dynamic recrystallization microstructures under hot working conditions, J. Mater. Process. Technol., 53 (1995), 349-361, doi:10.1016/0924-0136(95)01992-N

${ }^{10}$ H. Miura, T. Sakai, H. Hamaji, J. J. Jonas, Preferential nucleation of dynamic recrystallization at triple junctions, Scr. Mater., 50 (2004), 65-69, doi:10.1016/j.scriptamat.2003.09.035

${ }^{11}$ A. Momeni, K. Dehghani, Microstructural Evolution and Flow Analysis during Hot Working of a Fe-Ni-Cr Superaustenitic Stainless Steel, Metall. Mater. Trans. A, 42 (2010), 1925-1932, doi:10.1007/ s11661-010-0565-Z

${ }^{12}$ Y. Han, G. Liu, D. Zou, R. Liu, G. Qiao, Deformation behavior and microstructural evolution of as-cast 904L austenitic stainless steel during hot compression, Mater. Sci. Eng. A, 565 (2013), 342-350, doi:10.1016/j.msea.2012.12.043

${ }^{13}$ H. Mirzadeh, A. Najafizadeh, Hot Deformation and Dynamic Recrystallization of 17-4 PH Stainless Steel, ISIJ Int., 53 (2013), 680-689, doi:10.2355/isijinternational.53.680

${ }^{14}$ H. Monajati, A. K. Taheri, M. Jahazi, S. Yue, Deformation characteristics of isothermally forged UDIMET 720 nickel-base superalloy, Metall. Mater. Trans. A, 36 (2005), 895-905, doi:10.1007/s11661005-0284-Z

${ }^{15}$ W. S. Lee, C. F. Lin, High-temperature deformation behaviour of Ti6Al4V alloy evaluated by high strain-rate compression tests, J. Mater. Process. Technol., 75 (1998), 127-136, doi:10.1016/S09240136(97)00302-6 


\section{F. TEHOVNIK et al.: MICROSTRUCTURAL EVOLUTION OF INCONEL 625 DURING HOT ROLLING}

${ }^{16}$ H. Q. Sun, Y. N. Shi, M. X. Zhang, K. Lu, Plastic strain-induced grain refinement in the nanometer scale in a $\mathrm{Mg}$ alloy, Acta Mater., 55 (2007), 975-982, doi:10.1016/j.actamat.2006.09.018

${ }^{17}$ Y. Cao et al. An electron backscattered diffraction study on the dynamic recrystallization behavior of a nickel-chromium alloy $(800 \mathrm{H})$ during hot deformation, Mater. Sci. Eng. A, 585 (2013), 71-85, doi:10.1016/j.msea.2013.07.037

${ }^{18}$ S. Mitsche, P. Poelt, C. Sommitsch, Recrystallization behaviour of the nickel-based alloy 80 a during hot forming, J. Microsc., 227 (2007), 267-274, doi:10.1111/j.1365-2818.2007.01810.x

${ }^{19}$ Y. Wang, W. Z. Shao, L. Zhen, L. Yang, X. M. Zhang, Flow behavior and microstructures of superalloy 718 during high temperature deformation, Mater. Sci. Eng. A, 497 (2008), 479-486, doi:10.1016/ j.msea.2008.07.046 